\title{
DIREITOSHUMANOS E TRATAMENTO IGUALITÁRIO: questões de impunidade, dignidade e liberdade
}

\section{José Reinaldo de Lima Lopes}

No Brasil, parecia haver um certo consenso sobre o valor dos direitos humanos, no plano das afirmações doutrinárias e dos discursos políticos, muito embora houvesse limites à organização de partidos políticos e práticas policiais consolidadas de tortura e de repressão violenta. Foi, porém, como todos sabemos, a ditadura de 1964, reforçada pelo golpe dentro do golpe de 1968, que criou as condições para uma discussão prática dos direitos humanos e da sua efetiva proteção. Redemocratizando-se o país a partir da década de 1980, alteram-se progressivamente os termos do debate. Hoje, parece-me mais importante que nunca recuperar alguns pontos que nos anos imediatamente anteriores não foram suficientemente esclarecidos.

Cinqüenta e dois anos depois da Declaração Universal e 176 anos após a Declaração de Direitos da Constituição Política do Império, gostaria de fazer referência a dois temas. Em primeiro lugar, àquele sempre destacado pelos movimentos de defesa de direitos humanos no Brasil nos últimos 20 anos: a impunidade. Em segundo lugar, ao problema menos destacado, mas também fundamental, da defesa da autonomia da pessoa humana. A impunidade não se reduz a uma questão empírica ou da eficácia da lei: é reveladora de uma atitude moral. A desimportância atribuída à autonomia das pessoas procede de concepções autoritárias ou paternalistas e resulta que instituições liberais não conseguem se impor na sociedade brasileira. Ora, certos elementos da concepção liberal de vida e sociedade são inseparáveis da defesa dos direitos humanos. Minha idéia é, portanto, que sem o desenvolvimento e a aceitação mais generalizada desses elementos a defesa dos direitos humanos torna-se difícil. Em nossas circunstâncias, continua sendo prioritário justificar os direitos humanos para além de torná-los efetivos. É que a força da opinião contrária tanto facilita a impunidade quanto legitima 0 atual status quo de não realização dos direitos da pessoa humana.

A defesa dos direitos fundamentais da pessoa faz-se em duas esferas igualmente importantes. Uma, institucional, na qual se esclarecem os recursos que podem e devem ser colocados à disposição de qualquer um para sua defesa, e outra filosófica, justificadora destes direitos. Para alguns, a justificação já estaria completada pelas declarações de direitos mais recentes (a da ONU e as das constituições nacionais). Creio, no entanto, que esta justificação no Brasil ainda não se fez adequadamente, por motivos culturais e pelas nossas circunstâncias 
históricas. Quanto a estas, a industrialização, a urbanização e as migrações das três últimas décadas alteraram completamente 0 perfil de classe do país. Quanto à cultura, há não poucos juristas que lutam, mais ou menos abertamente, pela reforma da nossa Constituição por considerá-la excessivamente generosa. Há muitos cidadãos que pensam a mesma coisa. As práticas violentas na sociedade brasileira são preocupantes por demonstrarem quão superficial é sua aceitação entre nós.

Para os juristas, defender os direitos humanos significa duas coisas. Primeiro, colocar à disposição das vítimas os recursos institucionais de que dispõem (saber, profissão e assim por diante), uma prática advocatícia que incida diretamente no cotidiano. Uma segunda tarefa, que está em parte incluída na primeira, é a da argumentação e da justificação pública. Todo advogado, agindo em casos concretos, está argumentando. Defender alguém ou alguma causa, juridicamente, significa argumentar com base em normas. A despeito da corrupção, da chicana, ou dos embustes intelectuais que se apresentam como opiniões jurídicas e judiciosas, a simples aceitação de que o local próprio para a solução dos conflitos (ou de certos conflitos) é o foro já leva o operador jurídico a entrar para o mundo da argumentação fundamentada. Há, no entanto, uma argumentação que não se dirige ao caso concreto, mas à opinião pública, e cujo local de debate é mais amplo do que a arena bilateral de um caso forense. A todo momento estão a entrar novos membros nesta grande esfera de interação que é a sociedade e por isso é indispensável a todo momento falar de e justificar certos princípios. A todo momento as coisas mudam e novos casos concretos exigem nossa compreensão e a aplicação a eles de regras e princípios. A justificação dos direitos humanos é, portanto, tarefa permanente, como permanente é a sua reinterpretação.

Pretendo, a seguir, examinar aqueles dois pontos em particular - a impunidade e a cultura antiautonomia - e suas respectivas implicações para a defesa dos direitos humanos entre nós. No que diz respeito à impunidade, pretendo mostrar como, do ponto de vista normativo, ela é contraditória com 0 princípio da igual dignidade. Do ponto de vista prático, procuro dizer que sua existência degenera na quebra da confiança dos cidadãos entre si e na autoridade, gerando dificuldades de cooperação social (ou ação coletiva). A impunidade significa um tratamento desigual, e conforme se justifique por determinadas desigualdades resultará em desconsideração da igual dignidade de cada um. Como a autonomia pressupõe universalmente a dignidade de cada um e sua capacidade moral (não capacidade empírica) de determinar-se, 0 tratamento desigual da impunidade convive facilmente com o ethos da falta de autonomia paternal ou autoritário. Quanto à autonomia, pretendo, primeiro, apresentar os fundamentos de uma concepção universalista de direitos humanos e recolocar em destaque o papel atribuído à idéia de respeito, dignidade e liberdade. Esta idéia deve fincar raízes em termos políticos seculares, para superar o tom confessional que a luta pelos direitos humanos possa adquirir. ${ }^{1}$ Em segundo lugar, se os fundamentos apresentados forem suficientes, autonomia e respeito implicarão uma certa cultura cívica (desejável) de caráter democrático. 0 destaque para a necessidade de enfatizar os direitos de reconhecimento na atual circunstância brasileira aparecerá em contraponto com os direitos de redistribuição.

\section{A questão da impunidade}

A experiência cotidiana de qualquer brasileiro é a da convivência contínua com a impunidade: desrespeito à legislação de trânsito, desrespeito à legislação de zoneamento urbano, às leis de silêncio, às leis de preservação de áreas verdes nas cidades, sem falar naquele hábito nacional da cola nos colégios, quando as crianças já se socializam na cumplicidade contra o esforço da meritocracia. Dos crimes financeiros (previstos na Lei n. 7.492/ 86) inicialmente descobertos pelo Banco Central do Brasil e encaminhados ao Ministério Público, somente 3,9\% chegam à condenação. ${ }^{2}$ Estudo feito pela Comissão Justiça e Paz de São Paulo em 1993 mostrou que apenas $20 \%$ dos réus de homicídios contra crianças eram condenados.

A violência cotidiana, inclusive os linchamentos e extermínios, parece compensar diante 
da impunidade e da falta de recursos institucionais para a resolução de controvérsias. Seus números são assustadores. O Centro Luiz Freire, no Recife, revelou em 1994 que em dez anos haviam sido mortas 2.015 pessoas por grupos de extermínio em Pernambuco. Em São Paulo, as "chacinas" somaram 98 vítimas em 1995, e de janeiro a junho de 1998 já tinham resultado em 80 mortes. 0 número de homicídios de jovens no Brasil é também alto, tendo apresentado um crescimento de 9\% entre 1991 e 1994, enquanto nos EUA esse crescimento foi de $3 \%$. De uma maneira geral, 0 número de assassinatos no país triplicou entre 1979 e 1994 - de 11.194 para 32.350 vítimas de homicídio - , sem que a população tivesse triplicado, naturalmente, no período. Só o número de adolescentes mortos no período foi maior do que o de soldados americanos mortos na Guerra do Vietnã, que durou nove anos. De acordo com relatório da O uvidoria de Polícia de São Paulo de outubro de 1998, o número de denúncias de mortes de civis por policiais cresceu $278 \%$ de 1997 para 1998.

Já são conhecidos, nacional e internacionalmente, outros dados. Em 1992 a Polícia Militar em São Paulo matou 1.472 pessoas, sem que as taxas de criminalidade tivessem decrescido. No mesmo ano, em Nova York, a polícia matou 27 pessoas e em Los Angeles, 23 (a polícia de Los Angeles é considerada, nos EUA, uma polícia violenta). Entre janeiro e setembro de 1998 policiais militares paulistas mataram 331 civis (sendo 136 vítimas de policiais de folga). $\mathrm{O}$ aumento do número de mortos pela polícia não tem significado a diminuição da violência. 0 assassinato de camponeses (1.681 nos últimos 30 anos) não resulta geralmente em punição (15 condenações no mesmo período). Em abril de 1996, 200 policiais militares do Estado do Pará cercaram 1.500 manifestantes do Movimento dos Sem-Terra e o confronto resultou na morte de 19 civis $(1,7 \%$ dos presentes), alguns com sinais de terem sido mortos com tiros na testa e na nuca, a sugerir uma "execução". Isto sem contar as vezes em que a violência policial é tratada com explícita benignidade pelos tribunais e pela opinião pública, como no caso do massacre dos 111 detentos do Carandiru, em São Paulo, em 1992.
Um dos maiores méritos dos movimentos de base em defesa dos direitos da pessoa humana terá sido seu esforço exemplar, em vários casos espalhados em todo o país, para impedir que violações desses direitos caíssem no esquecimento e fossem tragadas pela prescrição nos escaninhos dos cartórios brasileiros ou nas escrivanias de polícia. Muitos centros de direitos humanos desenvolvem verdadeiras (e perigosas) investigações paralelas para apurar fatos, preservando provas, ouvindo testemunhas, municiando 0 Ministério Público com dados. 0 discurso que encontramos em toda parte é que é preciso acabar com a impunidade. Simultaneamente, os detratores da defesa dos direitos humanos costumam acusar os centros de defesa de promoverem a impunidade, ou os "privilégios dos bandidos" (Caldeira, 1992, pp. 362-378; cf. também Caldeira,1991).

Punição, democracia, dignidade

O tema da punição é, portanto, central no debate. Uns pedindo a punição dos violadores dos direitos humanos, outros pedindo a punição dos "bandidos". Para uma parte da população, os violadores de direitos humanos não são, propriamente, criminosos. Espancar, torturar, violentar, desde que se faça com alguém que "mereça" isto, não constitui propriamente crime ou violência. $O$ que se oculta por trás destas duas posições? Do ponto de vista jurídico, está aí a questão fundamental da punição justificada e devida, em ambos os casos. Por que, então, a divisão? Por que a falta de acordo?

A raiz do desacordo certamente está no entendimento do papel do direito e da autoridade estatal. Não são poucos os que querem um Estado vingador, capaz de fazer, por meio de seu braço armado, mais especificamente a polícia, uma espécie de justiça imediata e pelas próprias mãos. 0 Estado, pela polícia, faria as vezes da vítima e da legítima defesa. Esta noção tem algo de senso comum e não admira que seja, afinal de contas, tão popular. Pode-se dizer que corresponde a uma moral pré-crítica. Fazer com que o outro sofra uma punição, ou melhor, uma vingança, resulta de um impulso natural, uma paixão: aquele movimento interior que não se controla e que faz com que 0 agente sofra a ação em vez de realizá-la. 
O que há de verdadeiro, digamos assim, nesta noção é fundamental na filosofia do direito quanto à punição e às penas: elas devem ser merecidas, isto é, o culpado de algum crime deve "pagar" por ele, não pode safar-se, e a punição deve atingir o indivíduo cuja conduta é punível (o princípio da pessoalidade das penas). Isto já demonstra que uma boa parte do discurso contrário à defesa dos direitos humanos está fundada numa verdade básica para todo cidadão, ou seja, que a vida em sociedade organizada depende da defesa da liberdade e integridade da vida de todos e que, se todos se desarmam para ceder sua defesa à autoridade, dela esperam que seja capaz de manter minimamente a ordem e a paz. Por outro lado, espera-se que aqueles que violam estes mínimos sejam devidamente punidos, afinal de contas "paguem" alguma coisa.

O que parece equivocado é que a espécie de pena que se deseja cruel e a espécie de atuação que alguns propõem (e que de fato se realiza) nada têm a ver com um sistema democrático, universal, objetivo e seguro de aplicação da coerção e do direito de punir. É preciso distinguir, para tanto, entre a punição do Estado de direito e a simples vingança. E isto, parece-me, é mais difícil e está diretamente ligado à tradição autoritária e anticivil de nossa formação social.

Os traços da punição na sociedade democrática seriam sua universalidade e sua objetividade, significando que se estenderia de maneira geral a qualquer um que se encontrasse sob aquele sistema jurídico. Feitas as contas, parece que o Estado brasileiro não se mostra capaz de punir igualmente a todos. A justiça (a máquina de fazer justiça, incluídos os órgãos do Executivo - como a polícia, o Ministério Público, as agências fiscalizadoras - e do Legislativo - pela sua dificuldade de legislar adequadamente) parece ser seletiva e loté rica. $^{3}$ Esta incapacidade de fazer justiça universalmente significa, afinal, que o conjunto dos cidadãos não percebe com clareza e com rapidez que a justiça se faz conforme a lei. O próprio sistema judicial, com seus infindáveis recursos e com a completa autonomia de cada órgão, dá, ao fim, uma sensação de que tendo-se o advogado certo e sendo-se julgado pelo juiz certo ou pela câmara mais adequada do respectivo tribunal, pode-se sair ileso das garras da justiça.

Esta sensação generalizada de impunidade - que todos nós começamos a sentir dos bancos escolares, quando a cola pode correr solta, ou que testemunhamos no dia-a-dia do trânsito - resulta em descrença nas instituições e, para aqueles que menos refletem criticamente, em demanda para que a autoridade aja sem lei. Nesta ordem de idéias, associa-se a impunidade à legalidade: a lei é o que impede a justiça de se realizar da perspectiva destas vozes. A resposta adequada, segundo elas, é que a autoridade aja contra a lei, ou acima da lei. A fórmula é simples, e significa que 0 sistema legal não deve ser mais encarado com a perspectiva de que 0 poder precisa ser constituído e controlado. Passa-se a defender 0 poder discricionário e 0 uso imediato da violência. Há uma parte considerável da opinião pública, de todas as classes e estratos sociais, pode-se dizer, acreditando que o aumento da violência é fruto da "pouca energia" da polícia. Os números disponíveis, de fato, não mostram isto. Ao contrário, parece que há uma escalada de violência policial paralela à escalada da violência geral, sem que uma tenha sido capaz de conter a outra.

0 equívoco da posição de quem afinal termina aceitando uma polícia mais violenta está em que boa parte da impunidade, cuja cura se deseja, tem sido o resultado não da aplicação da lei, mas da incapacidade do Estado de aplicá-la. Para ser bem resumido: a sociedade brasileira, nos seus 176 anos de história institucional independente, tem sido incapaz de fazer aquilo que o Estado liberal mínimo prometeu, ou seja, aplicar universalmente a lei. Para esta incapacidade, o discurso contrário à defesa dos direitos humanos propõe indiretamente a abolição da lei. Ou melhor, propõe que alguns devem estar acima da lei, para poder disciplinar a sociedade.

Esta idéia de que alguém está acima da lei não se confunde com a idéia de que a autoridade goza de poderes de que o particular não goza. Mas os poderes da autoridade são limitados. Na história da filosofia política ocidental a submissão do rei à lei foi sempre reafirmada (lex facit regem, a lei é que faz 0 rei), a despeito de algumas correntes 
terem tentado dizer que o rei seria ab leges soluto, dispensado da lei, e tendo para com seus súditos apenas direitos. Os poderes da autoridade são diferentes dos poderes do particular pois sua razão de ser é sempre instrumental para o bem comum. A finalidade da autoridade é distinta da finalidade da vida de cada um.

O discurso pela punição dos "bandidos" vem permeado de ambigüidades na mesma medida em que a aplicação seletiva da lei quer dizer que há grupos, classes e interesses que conseguem ver-se protegidos pela lei. Assim é que a propriedade privada conseguiu estabelecer-se entre nós e grandes grupos econômicos operam aqui como operariam em qualquer outra parte, ou, a bem da verdade, deve-se dizer, com maior garantia e liberdade (isentando-se freqüentemente de impostos, de constrições ao direito de construir ou ao direito de usar os recursos ambientais e assim por diante). Outros interesses, no entanto, não conseguem impor-se da mesma maneira ou com igual facilidade.

O resultado da não aplicação da lei termina sendo, portanto, a violência pura e simples. Não é de se estranhar que 0 aumento da violência policial no Brasil seja seguido, nos últimos 20 ou 30 anos, do aumento da violência dos delitos.

Outro ponto a lembrar é a distinção indispensável entre 0 papel da violência do Estado e a violência do cidadão particular. 0 discurso antidireitos humanos tem, como já dito, seu fundo de verdade. Como não é crítico, leva a contradições graves. 0 Estado, concebido democraticamente e segundo a lei (o Estado de direito), pode exercer a violência de modo controlado. Trata-se de formas de constrangimento exercidas sobre os cidadãos com o propósito de garantir a igual liberdade de todos. O Estado e seus órgãos não são movidos pelo sentimento do indivíduo (ou pelas paixões individuais) e quando algum agente do Estado contamina sua atuação por algumas destas paixões trata-se de um caso de desvio: ou corrupção, ou falta de isenção, ou outra forma antijurídica de abuso de poder. A motivação do Estado é impessoal. Além disso, os meios à disposição da autoridade são outros: ela pode impor perdas de direitos, mas não pode insultar o cidadão, mesmo o criminoso, nem aviltá-lo física ou moralmente. Em outras palavras, ao Estado dá-se a faculdade de garantir a autonomia de todos, mas ao se transferir para 0 Estado este poder não se transfere a ele 0 exercício das paixões típicas das pessoas humanas, nem os mesmos meios de coação. O Estado não é um ser humano, assim como a pessoa jurídica não é um ser humano, e só metafórica e limitadamente podemos nos referir a eles como sujeitos. 0 que seria compreensível e até talvez justificável numa situação de conflito interindividual, algo como a legítima defesa, muda completamente de figura (de qualidade) quando se trata do Estado.

A violência entre particulares nem sempre tem por propósito estabelecer a igualdade universal. Quando ocorre, quer apenas afirmar a superioridade de um sobre o outro, garantindo um interesse exclusivamente pessoal. Entre indivíduos, o ponto de vista de cada um é individual; no Estado, o ponto de vista é o do cidadão. No caso da violência entre indivíduos, do ângulo daquele injustamente agredido, trata-se de fazer valer o seu direito pessoal (à vida, à liberdade etc.), que é tão bom e tão valioso quanto o do seu agressor. 0 Estado não é um vingador dos indivíduos, mas 0 garantidor de igualdades. Isto torna compreensível que a vítima queira uma justiça que a justiça criminal não lhe pode dar. A vítima procura uma compensação que a justiça civil lhe dá sob a forma de indenização. No direito antigo, as penas, especialmente as multas, não eram devidas ao Estado, mas à própria vítima. $\mathrm{O}$ Estado ou a comunidade, no direito antigo, não recebiam nada: apenas supervisionavam a imposição da pena pela vítima ou pela sua família.

Separando-se os pontos de vista do indivíduo e do cidadão, chegamos ao tema dos direitos humanos como garantia da vida democrática. Quando os movimentos de defesa dos direitos humanos insistem na punição dos violadores de direitos fundamentais da pessoa humana estão reafirmando 0 poder do Estado em fazer valer universalmente a lei. Isto quer dizer garantir direitos e não privilégios, pois a rigor a lei beneficia a todos.

Um outro argumento no debate consiste em questionar se os violadores da dignidade de seus 
semelhantes, da pessoa humana, perdem eles mesmos a dignidade. Se isto for assim, junto com sua dignidade os criminosos perdem também 0 respeito que seria devido a todo ser humano. Por isso, violar-lhes os direitos, a integridade ou a pessoa seria justo, merecido, "bem-feito", diriam alguns.

Para outros, agredir a dignidade do outro, de qualquer modo, não implica perda da própria dignidade, ou melhor, não implica que o outro a vítima, mas sobretudo os terceiros - deixe de considerar o agressor (ou delinqüente) como pessoa. Já que as noções de dignidade e respeito exigem que o sujeito racional reconheça a dignidade humana em si mesmo e nos outros, o mal sofrido não deveria - racionalmente - fazer com que a vítima deixasse de reconhecer 0 valor de pessoa humana do outro. Trata-se, portanto, do paradoxo do sujeito digno: reconhecer, nas condições mais difíceis, a dignidade alheia, mesmo daquele que não vive a reciprocidade do respeito universal. "Sofrer a injustiça, antes que praticá-la." A rigor, só enquanto se considerar o criminoso como pessoa é que se pode aplicar-lhe a pena, pois só assim se estaria reconhecendo sua capacidade de dar-se conta da sua própria ação.

Restaria recordar a natureza especial das violações dos direitos humanos. Dá-se em situações especiais, que infelizmente são mais rotineiras quanto mais desigual e estratificada é uma sociedade. A diferença fundamental pode ser encontrada na qualidade das partes envolvidas. Uma violação aos direitos humanos implica que o violador tem, em relação à vítima, uma posição de superioridade ou ascendência, ascendência social, política, econômica. 0 violador é também uma espécie de representante de uma política ou um ethos (ou seja, uma atitude dominante ou generalizada) de um grupo que também tem ascendência social, política ou econômica sobre o grupo dentro do qual se insere a vítima. Isto faz a diferença entre os crimes comuns e a violação dos direitos humanos. 0 crime comum diz respeito à violência de um particular contra outro particular. O crime de violação de direitos humanos é qualificado: contam as motivações de forma diferente (por exemplo, os crimes de ódio, cometidos contra uma pessoa apenas por sua pertença a determinado grupo, em oposição aos crimes praticados aleatoriamente) e contam também as qualificações do autor e da vítima (alguém investido de autoridade, ou alguém associado a grupos com propósitos específicos de aterrorizar grupos de cidadãos definidos etc.).

Finalmente, no que diz respeito à impunidade, como em geral sabemos e como periodicamente nos recordam as ciências sociais, ela é um forte estimulante ao desrespeito à lei. E 0 desrespeito à lei, numa sociedade complexa profundamente dividida em classes e grupos de interesse, tende a gerar 0 aumento da violência. Da parte das vítimas de crimes comuns, pode gerar demandas de mais violência pela polícia ou de maior apoio a grupos de vigilantes e justiceiros. Da parte dos delinqüentes, a inexistência de proporção entre delitos e pena generaliza-se em maior violência. Em ambos os casos, solapam-se as bases de uma convivência democrática, pelo descontrole do arbítrio do Estado ou pelo descontrole da violência do cotidiano.

Impunidade e efeito carona: a face moral da ação instrumental

O efeito carona é um problema da ação coletiva ou da cooperação. O carona viaja sem pagar os custos, ou, em termos político-sociais, obtém o bem coletivo (fruto do esforço comum) sem ele mesmo colaborar, sem pagar-lhe o preço. A impunidade significa isto: o fardo da convivência, ou seja, o preço de viver em sociedade deixa de ser pago por algum ou alguns. A impunidade ou dissolve progressivamente o pacto social, forçando uma corrida para baixo e para trás, ou gera crescente ineficiência em termos de ação coletiva. É evidente, diz Rawls (1992, p. 268),

que a indivisibilidade e a publicidade, assim como as externalidades, precisam de acordos coletivos garantidos (enforced) pelo Estado. Mesmo entre pessoas justas, uma vez que os bens sejam indivisíveis para um número grande de indivíduos, suas ações, deliberadas em isolamento uns dos outros, não conduzirão ao bem geral. [...] Alguma forma de acordo coletivo é necessária e cada um quer a garantia de que será preservado se estiver disposto a fazer a sua parte. Em comunidades grandes 0 
grau de confiança recíproca na integridade do outro, e que dispensa a coerção, não é de se esperar.

Pode-se dizer que um sistema de normas é um facilitador da ação coletiva ou da cooperação. Sabendo que há um padrão obrigatório, os agentes podem fazer individualmente suas escolhas contando com a regularidade do sistema. A teoria dos jogos propõe modelos de ações coletivas nas quais presume que cada agente procura maximizar os benefícios individuais da sua ação, sabendo que todos os outros fazem o mesmo. O resultado final da interação de todos, ou o "resultado do jogo", não é, portanto, apenas o resultado da ação de um jogador. Há vários resultados possíveis, alguns mais eficientes do que outros. As regras constituem o jogo, de modo que todos os participantes seguem a regra, todos os jogadores são jogadores por força das regras (pensemos nas regras de pertença, que vão desde a pertença voluntária a grupos específicos - como clubes e igrejas - até regras de pertença involuntária a grupos abertos - como a cidadania ou a humanidade). 0 jogador que burla as regras, quando todos os outros as cumprem, é o carona. Ele tenta manipular o resultado do jogo conforme as regras para, contra as regras, obter vantagem "indevida".

Quando a certeza ou grande probabilidade de sair impune vigora, toma-se racional, para cada um, individualmente, tentar escapar dos encargos da ação. 0 resultado do jogo neste caso, em que os dois jogadores desertam (isto é, agem individualmente contando com a cooperação dos outros e não com a sua), é sub-ótimo para ambos. Exponenciado para circunstâncias em que não há apenas dois mas muitos jogadores, o jogo da impunidade, chamemos assim, gera uma corrida social para baixo e para trás. Dissolve-se progressivamente a confiança no funcionamento dos estímulos institucionais para cooperar e crescem os estímulos para não cooperar. Pensando apenas em suas respectivas soluções individuais, todos convergem para uma falta de solução coletiva. 0 exemplo cotidiano mais evidente está no trânsito "engarrafado" nos semáforos. Se imagino que os outros não vão parar no sinal vermelho, antes, se imagino que vão avançar, ou melhor, se tenho certeza de que vão avançar, prefiro avançar em primeiro lugar eu mesmo. Como resultado, todos avançam e 0 cruzamento fica bloqueado. Todos perdem 20 minutos para atravessá-lo. Se, ao contrário, todos obedecessem o semáforo, cada um perderia apenas dois minutos. Se eu, porém, obedecer e ninguém mais obedecer, termino perdendo 30 minutos, pois os mais espertos "desertam" antes e, com a certeza da impunidade, atravessam antes de mim.

Alguns reconhecem na teoria dos jogos antigos problemas da teoria moral ou da razão prática. Certo que a razão prática pode não ser tratada como simples razão estratégica, mas também é certo que a razão estratégica não pode ser desconsiderada. O dilema do prisioneiro é exemplar do problema da confiança recíproca: sem ela, a ação coletiva (ou ação comum) torna-se mais custosa e ineficiente. Com ela, a cooperação fica facilitada. A lei e a autoridade são elementos de garantia ou estímulo à confiança recíproca. Elas devem representar 0 ponto de vista do cidadão, não do indivíduo (como queria Rousseau). A estratégia individual, consistente em agir conforme se tenha ou não confiança recíproca, é confrontada com outro ponto de vista também racional. Trata-se do ponto de vista universal do dever, para explicar com a linguagem de Kant.

Do ponto de vista exclusivamente individual pode ser racional para 0 agente desertar (não cooperar). O resultado é maximizado se ele for 0 único a desertar e todos os outros cooperarem. Mas se os outros fizerem a mesma coisa, o resultado final e global será perverso: o que é racional para um, em particular, torna-se tragicamente irracional para todos ao mesmo tempo. Ora, dizem alguns, é justamente isto que o imperativo categórico de Kant visa descobrir: agir de tal modo que a máxima (regra) da sua ação seja considerada como regra universal. Se do ponto de vista universal não posso querer a deserção (não cooperação) de todos, pois a rigor ela destruiria minha vantagem pessoal, torna-se irracional querê-la apenas para mim, irracional do ponto de vista moral. $\mathrm{O}$ agente imbuído do senso moral que lhe dá a "descoberta" do imperativo categórico é capaz de reverter as expec- 
tativas, reinstalando confiança. Naturalmente é preciso que haja um "certo número" de agentes com esta forma de agir (Hargreaves e Varoufakis, 1995, pp. 155-156; Nino, 1992, p. 197; Elster, 1994, pp. 192-202).

O dilema do prisioneiro mostra que a não cooperação pode ser ineficiente do ponto de vista dos resultados, pois a quebra da confiança (a não cooperação) termina resultando no rebaixamento geral das condições em que se encontram os atores sociais. Esta é parte da contradição interna de um sistema capitalista descrita por Marx ao lembrar que 0 capitalista individual não pode querer para todos os capitalistas aquilo que quer para si. A lógica da concorrência chega a ser contraditória com a lógica da cooperação. Lógica, neste contexto, significa a razão de decidir, ou a justificativa da ação, ou a "regra" da ação. Decide-se em função de uma regra, que tanto pode ser a descoberta formal do dever (como na reflexão que leva ao imperativo categórico) quanto a avaliação dos resultados da ação (como é da tradição utilitarista). ${ }^{4}$ Ora, nos jogos competitivos ou nas relações de oposição, como diziam os juristas antigos (o contrato exemplar aqui é a compra e venda), o fim da ação é a supressão do benefício do outro. Há troca, comutatividade, sinalagma para cada um: a soma zero. $\mathrm{Na}$ cooperação, nos jogos cooperativos ou de resultado não zero, a finalidade da ação é a manutenção do outro como parceiro (ou sócio, daí os contratos de sociedade serem exemplares destas situações).

A impunidade, a corrupção e outras formas de comportamento social predatório são estimuladas também pelo fracasso da autoridade pública. A autoridade, no Estado de direito, é naturalmente a autoridade da lei. Seria fácil, mas incompleto e por isso mesmo enganoso, imaginar que a questão da autoridade diz respeito a um problema vertical da relação do "governo" com o "povo", ou de pura obediência. É mais adequado perceber que se trata de um problema horizontal: da relação dos cidadãos entre si, ou de uma parte do povo com a outra parte, ou de uma parte com todos. 0 tema é o do respeito recíproco, que implica uma noção universal de liberdade e dignidade. J.S. Mill (1974, pp. 128-132) notara que uma vez estabelecidos os princípios da liberdade política sob a forma da soberania popular, surgia imediatamente a questão da liberdade civil, ou seja, da opressão recíproca que os membros do povo exerceriam sobre si. Muito embora sua preocupação fosse com a tirania da maioria sobre as minorias em termos de opinião, costumes ou vida privada, faz sentido pensar que na sociedade democrática, em que os estados (status) e a honra não devem contar, a discriminação na aplicação da lei, a criação de grupos impunes, resulta em uma forma de opressão de uma parte do povo por outra.

0 fracasso da autoridade ou, quando equivalente, 0 fracasso do respeito à lei degenera em formas de anomia. Como observou Elisa Reis (1995, p. 43):

As iniciativas tomadas na esfera privada para compensar 0 fracasso do Estado na manutenção da ordem pública e da segurança acabam por agravar o problema. A generalização da prática de contratar segurança particular e serviços de guarda-costas, o pagamento de dinheiro em troca de proteção, a criação de esquadrões da morte, a privatização de facto dos espaços públicos através dos bloqueios de ruas e medidas semelhantes, tudo isso evidencia o que poderíamos chamar de uma espécie de pretorianismo social na região [América Latina], para usar uma expressão de Huntington: a generalização do recurso a meios violentos, e a competição por esses meios, que desmoralizam ainda mais a autoridade pública. É cada vez mais provável que se venha a produzir alguma forma ampliada de familismo amoral, quanto mais os atores (individuais ou coletivos) concebam essas ações preventivas como sua melhor alternativa.

Muitos, inclusive juristas, analisaram estes problemas de impunidade no Brasil. Cito apenas dois exemplos que mostram não só o quanto isso já dura, mas especialmente como impede a construção de uma vida democrática mais plena. Carneiro de Campos, analisando o projeto de Código Criminal do Império em 1830, lembrava que 0 direito penal das Ordenações Filipinas parecia aos juízes e desembargadores excessivamente rigoro- 
so. Para evitar a crueldade da lei, recorriam eles a expedientes constantes para deixar de aplicá-la.

O Código antigo era monstruoso, era cruel, era inexeqüível, e por essa razão é que muitas vezes os criminosos ficam impunes. [...] Eu estive na Relação, vi muitas vezes que em regra era "morra por ele" e nós nos lançávamos, portanto, num sistema oposto de que resultava uma espécie de arbitrariedade nos juízes. (apud Leal, 1922, p. 1.143)

A "misericórdia" dos juízes aplacava o rigor da lei, mas o resultado, como dizia Carneiro de Campos, não era positivo: de um lado a impunidade dos criminosos, de outro a arbitrariedade dos juízes. Nenhuma da duas coisas é compatível com 0 sistema de iguais liberdades democráticas. Por isso, o que ele esperava de um código criminal mais adequado era a consolidação de um certo estatuto de legalidade, em que nem os criminosos se livrassem por favor (ou graça), nem os juízes fizessem a lei ad hoc ou ad hominem, conforme seu sentimento no dia e no caso.

Oliveira Vianna intui também que a impunidade é antidemocrática. Lembra, em primeiro lugar, que as liberdades civis são indispensáveis:

Garantir a liberdade civil ao povo-massa: eis o problema central da organização democrática no Brasil. [...] Esquecemo-nos de que jamais poderemos realizar essa regeneração da nossa vida política com que sonhamos sem termos garantido, previamente, aos cidadãos do povo-massa estas liberdades da vida privada. E 0 aspecto mais urgente desse problema é assegurar estas liberdades contra 0 arbítrio das autoridades públicas principalmente as autoridades locais.(Vianna, 1987, p. 150)

\section{E prossegue:}

Nem a generalização do sufrágio direto, nem 0 self-government valerão nada sem 0 primado do Poder Judiciário - sem que este poder tenha pelo Brasil todo a penetração, a segurança, a acessibilidade que 0 ponha a toda hora e a todo momento ao alcance do Jeca mais humilde e desamparado. [...] De nada valerão a esses desamparados e relegados, entregues aos caprichos dos mandões locais, dos senhores das aldeias e dos delegados cheios de arbítrios, estas regras políticas, desde que os eleitos por este sufrágio universal e direto - sejam funcionários municipais, sejam estaduais, pouco importa - estiverem certos que poderão descumprir a lei ou praticar a arbitrariedade impunemente. (idem, pp. 159-160)

Talvez lhe fosse pela mente esta percepção - com todas as restrições que se possam fazer a suas lealdades políticas - de que na esfera da coordenação, ou do respeito recíproco dos cidadãos (na esfera de uma sociedade liberal), o Estado deveria intervir para garantir a horizontalidade das relações e ali ser eficaz o suficiente para despertar o sentimento de que valeria a pena cumprir as leis no confronto com seus vizinhos. Não seria incabível lembrar ainda a perspectiva clássica de Sérgio Buarque de Holanda (1963, pp. 129-144), segundo a qual o homem cordial é avesso à polidez (ou à etiqueta, a pequena ética) e só aparentemente é educado (polido): é também avesso às distinções entre 0 público e 0 privado e, portanto, à autonomia alheia, diria eu.

Em resumo, a defesa dos direitos humanos depende em medida importante da redução dos níveis de impunidade. Do ponto de vista da filosofia do direito, a impunidade não se sustenta nem se justifica; do ponto de vista das condições da vida política de cidadãos livres tampouco, pois seu resultado é perverso.

\section{A autonomia e a liberdade: fundamentos dos direitos humanos}

0 discurso sobre os direitos humanos tem sido marcado por apelos à "dignidade" da pessoa humana. Em que propriamente consiste esta dignidade pode ser objeto de debate. Creio que se podem formular duas grandes linhas de entendimento: uma de um ponto de vista substantivo e outra de um ponto de vista procedimental.

De caráter substantivo seriam aquelas definições que fazem de certas qualidades de caráter 
um componente essencial da dignidade. Tendem a tratar a dignidade como um valor, ou seja, um objeto ideal. Tendem também a ser prescritivas, determinando que certas maneiras de ser são mais ou menos dignas. Uma conseqüência possível de perceber assim a dignidade da pessoa humana é assumir prescrições de comportamento bom, cujo resultado tem dois lados. Em primeiro lugar, aqueles que não atingem 0 ideal substantivo de pessoa digna passam a ser tratados com certa condescendência ou paternalismo. 0 apelo à dignidade resulta em comiseração neste caso. Em segundo lugar, esta condescendência ou paternalismo, esta "tolerância" no sentido negativo do termo (tolera-se o que a rigor se poderia suprimir), gera uma atitude política de corte autoritário. Esta concepção de dignidade como um status ideal a ser atingido provoca a divisão em estratos: a humanidade tem pessoas mais ou menos dignas, como se dividiam as pessoas em sociedades aristocráticas, oligárquicas, de classes ou de castas. Deste mesmo ponto de vista, uma tarefa da elite, do governo ou da autoridade é tornar os homens bons, sendo condescendente com os que não logram atingir o ápice dos ideais substantivos e normativos compartilhados pelo grupo dos bons, da aristocracia moral da humanidade. Quem não vive como este grupo vive abaixo do padrão de dignidade. Esta idéia resulta, afinal, e paradoxalmente, no demérito dos que não atingem o ideal objetivo (e exterior à pessoa) proposto, que perdem a sua dignidade (e podem perder seus direitos). ${ }^{5}$ De um instrumento de defesa das pessoas, a expressão dignidade termina por transformar-se em instrumento de exclusão. Uma aristocracia moral tenta desqualificar seus interlocutores.

A segunda linha de definição é de matriz moderna e recebe em Kant uma formulação mais elaborada. Ele define a dignidade humana na Fundamentação da metafísica dos costumes. Diz que no reino dos fins tudo tem um preço: tudo pode ser escolhido e, portanto, trocado no universo da liberdade. Aquilo que não pode ser trocado, substituído e que não tem equivalente não tem preço: seu valor chama-se dignidade. Não há equivalente, não há comensurabilidade no que diz respeito àquilo que é um fim em si, que não pode ser objeto ou instrumento de nenhuma ação. Este fim em si é o sujeito racional, a pessoa humana. Os seres humanos devem reconhecer-se como fins em si mesmos, devem reconhecer a humanidade em si e nos outros. Este reconhecimento recíproco da dignidade de cada um é o respeito. Respeito significa uma espécie de amor impessoal, "não patológico", como diz o mesmo Kant. $\mathrm{Na}$ idéia de respeito encerra-se uma forma de reconhecimento, de consciência refletida da minha identidade na identidade dos outros. Esta idéia será retomada em Hegel: ao contrário da família e da sociedade civil, em que os laços afetivos ou as trocas fundadas nas necessidades se estabelecem, é no âmbito do Estado (e, pois, do direito público e político) que 0 reconhecimento impessoal se conclui, afirmandose um respeito pelas diferenças e ao mesmo tempo estabelecendo-se um sentimento de solidariedade.

Com todas as enormes discussões que 0 ponto de vista kantiano pode suscitar, creio que, para a teoria dos direitos humanos, ele é até hoje fundamental. Sua implicação mais importante está numa antropologia da liberdade. A dignidade da pessoa está ligada à sua capacidade de agir humanamente, e agir de maneira humana é agir livremente, deliberando, escolhendo seus planos e seus fins.

Fazer valer tal liberdade é o propósito de uma doutrina dos direitos humanos. A liberdade é uma condição da vida humana, mas não é uma condição dada. Seja como livre-arbítrio, seja como liberdade civil, a liberdade resulta de ações e exercícios. Embora haja uma condição de liberdade na ação humana, ela precisa ser cultivada, assim como as virtudes, para Aristóteles, ou os sentimentos morais, para os utilitaristas, ou o juízo crítico, para Kant. A liberdade moderna, significando ausência de coação, exige a tarefa crítica de conhecer e determinar o que de fato coage e limita a vida dos homens. As coações podem ser internas (subjetivas) ou externas (objetivas), mas independentemente de sua característica é preciso opor-se a elas quando injustas, indevidas ou inutilmente cruéis. Este "é preciso" é prescritivo e ideal: não há nada, no universo dos fins, no reino da liberdade, que determine (à moda das regularidades naturais) a 
ação humana. Claro, trata-se de ações humanas, não de ações de "animais irracionais" e nem de "anjos"; existe um ponto de vista humano e uma condição humana dos quais não se escapa e que, portanto, determinam a ação. Mas dentro destas circunstâncias humanas, entre as quais está a faculdade de exercer autonomamente suas razões, é possível exercer a liberdade.

Deste ponto de vista a dignidade é um reflexo da liberdade de cada um, ou seja, da consideração de que cada um é capaz de agir como sujeito, como fim de si mesmo e para si mesmo, e de internalizar criticamente regras, máximas, imperativos, leis de decisão. A dignidade humana vem não do seu modo de vida, mas da sua capacidade de ser fim em si mesmo, de ser livre (contrariamente ao objeto, que não se determina, mas é determinado, e que, por isso mesmo, não é livre). A extensão deste ponto de vista significa a extensão da liberdade, proteção crescente às escolhas e às condições que permitem as escolhas. A tolerância torna-se, pois, ativa e não admira que se verifique hoje o desenvolvimento de uma linha de pensamento que diz respeito ao reconhecimento das diferenças. A tolerância deixa de ser apenas aceitação passiva do que não se pode evitar (a tolerância deixa de ser resignação ou conformismo) para ser 0 reconhecimento da pluralidade das realizações da vida humana (Oliveira, 1996; Appiah, 1998).

Como resultado, o respeito à igual liberdade de todos tende a favorecer uma perspectiva menos autoritária da vida social. Já não há um ideal substantivo a ser atingido e a autoridade não precisa zelar para que todos cheguem a ser pessoas dignas no sentido aristocrático do termo. Não é só na relação entre autoridades e cidadãos que a perspectiva muda: as relações entre cidadãos e cidadãos são percebidas mais horizontalmente. Cada um aprende a ver-se como um observador entre outros. Cada um assume uma dúvida fundamental: no confronto das opiniões, eu e minha comunidade cultural podemos estar eventualmente errados. Fundamentalmente, reconhecemos que os outros aderem a outras crenças, convicções, formas de vida e comportamentos por sua própria capacidade de seres livres. Esta restrição às interdições (a tolerância) funda-se neste motivo:
Esse motivo é certamente 0 mais difícil de assumir: é a presunção de que a adesão do outro às suas crenças é, ela mesma, livre. Só essa presumida liberdade situa a crença sob a categoria da pessoa e não da coisa e, ao mesmo tempo, a torna digna de respeito. [...] Não se deve objetar aqui que 0 pertencimento a uma confissão, a uma tradição cultural, é um destino que se assemelha muito a um determinismo. Pois precisamente 0 respeito consiste em presumir na adesão um elemento de liberdade, o qual basta para fazer do próprio destino uma categoria da liberdade e não do determinismo. (Ricoeur, 1995, pp. 183-184)

Por isso se argumenta, porque se acredita que 0 outro pode chegar a entender minhas razões e é capaz, ele também, de dar razões para seus atos e crenças. Não presumo sua estupidez ou incapacidade.

Em resumo, duas podem ser as fundamentações da dignidade da pessoa. Uma delas, a segunda, presume a liberdade e, a partir dela, deriva conseqüências normativas. Esta liberdade de que se fala até aqui, portanto, é também autonomia: capacidade não apenas de estar livre de interferências, mas também de escolher crítica e autonomamente um plano de vida, uma narrativa de identidade, uma fonte moral do próprio eu (Taylor, 1996, pp. 91-98).

A noção de autonomia tem implicações que a tornam revolucionária em certas circunstâncias sociais. Quando as práticas, a cultura e as instituições promovem - estimulam - as distinções é muito mais difícil estender a proteção dos direitos humanos a todos, universalmente. Pode-se pensar em várias espécies de diferenças. Há as diferenças em relação à pertença a certos grupos: os de dentro são os iguais, os de fora são os desiguais. Toda classificação implica esta idéia: 0 indivíduo está dentro ou fora da classe. A humanidade, na concepção moderna, é por excelência classe universal (qualquer exclusão precisa ser justificada, se é que pode ser justificada). Há as diferenças de caráter vertical: de ordem social e econômica (os excluídos), os de baixo e os de cima. Ainda de caráter, digamos, vertical existem as diferenças de reconhecimento: os melhores, os piores, os mais dig- 
nos, os menos dignos. Existem diferentes diferenças: algumas são diferenças a serem preservadas, avaliadas positivamente, outras são as diferenças a serem suprimidas, avaliadas negativamente (Oliveira, 1996). E há, naturalmente, 0 mar das diferenças ambíguas. Por exemplo: diferenças culturais podem ser valorizadas positivamente, criando-se então proteção jurídica para que sejam promovidas ou mantidas. Um Estado democrático valoriza positivamente a pluralidade. As diferenças podem ter um caráter meramente horizontal, sem gerarem opressões ou exclusão, mas há as diferenças econômicas e sociais que excluem. Enquanto para as primeiras o remédio é a igualdade, para as segundas o remédio pode ser valorizá-las (criar o orgulho pela diferença) ou borrá-las (desonstruir as identidades impostas).

É fato que as identidades, e portanto as formas de reconhecimento, se estabelecem contrastivamente: grupos de iguais se identificam ao diferenciar-se dos grupos de seus desiguais. A noção de direitos universais potencialmente choca-se com a noção de identidades, ou seja, de existência e proteção dos desiguais e das desigualdades. Em discurso famoso pronunciado em 23 de dezembro de 1789 na Assembléia francesa, o conde de Clermont Tonnerre afirmava que era preciso tirar tudo dos judeus como nação (grupo) para darlhes tudo como cidadãos. Na qualidade de cidadãos todos se igualavam e a lei deveria ser este esforço de igualação.

Ao mesmo tempo, a lei que constitui a cidadania deve garantir os planos de vida (autonomia) dos indivíduos, que por sua vez se realizam também na busca dos seus semelhantes, em associações privadas de todas as naturezas e nas manifestações públicas destas associações. A extinção da religião de Estado não deveria significar o confinamento da atividade religiosa ao interior das casas de família, mas a possibilidade do culto público, em ordem e em paz, de todas as religiões, sem que nenhuma delas recebesse especial apoio dos fundos públicos. Em outras palavras, a polícia garantiria para todos a mesma ordem, mas o fisco não daria incentivos a qualquer um em particular. Em resumo, a liberdade da vida privada pode constituir-se também em liberdade no espaço público e liberdade de não ver aviltada a imagem coletiva do grupo a que se pertence.

Pode-se entender que a liberdade, ausência de interferência em âmbitos da vida que dizem respeito à própria satisfação, quando não há dano a outrem, é que permite a autonomia, isto é, a realização da vida de cada um da maneira que lhe parecer mais conforme a sua consciência. Dentro deste espírito, as manifestações culturais das vidas de cada um em grupos de identidade são compatíveis com a igualdade e a liberdade universais.

Mas isto não se faz sem um progressivo reconhecimento de esferas de liberdade às quais se deve estender a noção de respeito e dignidade. Dois exemplos importantes podem ser dados no Brasil: os direitos de reconhecimento devidos aos homossexuais e às culturas indígenas. Os primeiros ainda sofrem de enorme discriminação social e política, faltando a uma parte considerável dos juristas a sensibilidade para a dignidade do grupo (ou seja, o respeito a um modo de vida e a manifestações coletivas deste modo de vida). Não são poucas as vozes que publicamente se manifestam de forma pejorativa e discriminatória contra os homossexuais, encontrando ambiente favorável na cultura e nos preconceitos religiosos, populares, pseudocientíficos herdados da preeminência do positivismo de um século atrás. No caso dos povos indígenas, a especial proteção parece ser aceita de modo geral, mesmo porque explicitamente reconhecida na Constituição, mas as formas de defesa propostas demonstram as diferenças de compreensão do que é o valor de uma cultura, sem mencionar as atitudes mais evidentes de não reconhecimento: o desprezo pelo valor de tais formas de vida, ou uma espécie de paternalismo encantador e idealizador. No primeiro caso os outros são menos que gente, e no segundo, quase anjos. Nos dois casos não se estabelecem interações de reciprocidade, que envolvem simultaneamente valorizar e criticar a forma de vida alheia.

\section{A utonomia e democracia}

A perspectiva da liberdade como fundamento da dignidade alheia é difícil de aceitar. Esta dificuldade deriva de duas ordens de problemas, que examinarei a seguir. Antes, porém, de entrar neste 
exame convém fazer uma observação geral sobre 0 respeito à autonomia e 0 ideal democrático.

Tem razão Jessé Souza (1998, p. 112) quando procura distinguir duas formas de associação, ou melhor, duas "formas alternativas de solidariedade social em sentido amplo". Valendo-se da distinção weberiana entre seita e igreja e da interpretação de Bellah, Souza destaca que a primeira forma, a solidariedade de seita, é ao mesmo tempo altamente exclusiva e capaz de gerar confiança intersubjetiva, justamente porque a seita é uma forma de associação voluntária. Ao contrário, a solidariedade de igreja prioriza o organicismo e o todo, que antecede suas partes, seus membros. Como a igreja recebe a todos, seu mecanismo de inclusão não é mais o dentro/fora, o que pertence ou não a ela: é o superior/inferior, é a hierarquia e o elitismo. Todos pertencem, mas nem todos ocupam lugar semelhante. Em vez de uma comunidade de iguais (horizontalmente coordenados), uma sociedade de desiguais (hierarquicamente submetidos). 0 problema da solidariedade de igreja é a igualdade: sendo hierárquica, não predispõe para 0 associativismo democrático. 0 problema da solidariedade de seita é a exclusão: sendo horizontal, seu instrumento de identidade é excluir os "infiéis". Naturalmente, trata-se de tipos-ideais weberianos, mas podem servir de introdução ao nosso tema, isto é, à liberdade e à autonomia que inspiram os princípios dos direitos humanos e que tanta polêmica causam quando se pretende sua universalização.

Voltemos aos problemas da liberdade fundada na dignidade alheia. Em primeiro lugar surge um obstáculo de caráter subjetivo: desenvolver a capacidade de usar a razão de modo dividido, ou seja, sendo capaz de colocar-se no lugar do outro, admitir a perspectiva chamada imparcial. Trata-se da busca do ponto de vista a partir do qual avaliar as escolhas sem levar em conta de forma exclusiva ou preeminente o seu próprio benefício. Cada pessoa deve aprender a fazer este uso de sua razão, daí chamar este primeiro ponto de obstáculo subjetivo. Colocar-se no lugar de qualquer um é adquirir uma faculdade para exercer a "razão prática", a deliberação moral e política. Ao longo da história muitos nomes foram dados a esta capacidade: em alguns momentos chamaram-na virtude, ou hábito da vontade; em outros, sentimento moral. Reconhece-se, em geral, que esta capacidade é natural aos seres humanos, embora dependa de ser cultivada. Mesmo os utilitaristas, cujas premissas e conclusões tanta discussão geram, insistem que a felicidade valiosa e moralmente relevante não é exclusivamente a minha, mas a de todos. Agir para maximizar a felicidade (ou utilidade) de todos é uma forma de ser indiferente, isto é, imparcial.

Este ponto de vista imparcial exige reconhecer as semelhanças, querer 0 que todos querem. Em toda nossa tradição filosófica este esforço insisto, é um esforço - de elevar-se de suas próprias circunstâncias para atingir um ponto de vista universal vem sendo debatido e justificado. Há, portanto, um problema de ponto de vista, resultado de esforço pessoal que se aprende e se desenvolve. Como se trata de um aprendizado, este se dá como fruto de uma experiência no confronto com o mundo social. Na ordem aristotélica da explicação, trata-se de um discemimento que se aprende discernindo e submetendo suas razões de decidir ao teste da consistência e da coerência. Só o sujeito experimentado, dirão Aristóteles e Mill, é capaz de escolhas, já que escolher bem é fruto de um aprendizado. Do ponto de vista da escolha das regras, a experiência que se exige é também uma experimentação, ainda que hipotética, das regras. A capacidade de formular as hipóteses também se adquire e refiná-las é um exercício de razão pura prática, se seguirmos a tradição de Kant. $\mathrm{O}$ que quero dizer é que é preciso desenvolver esta capacidade de escolha. ${ }^{6}$

A segunda ordem de problemas chamo de objetiva porque deriva dos arranjos políticos e institucionais que podem reforçar ou não o exercício da deliberação política do ponto de vista do cidadão. Uma sociedade democrática exige instituições democráticas que a sustentem, embora instituições políticas e jurídicas não resultem, por si, em práticas liberais (associativas e democráticas, para usar a tipologia antes citada). É preciso incentivo institucional para que o ponto de vista do outro seja levado em consideração. 0 sistema jurídico desempenha este papel. Mesmo que os sujeitos não sejam bons, mesmo que não tenham 
adquirido virtude, ou consciência crítica suficiente para agir segundo o modelo do bem ou do imperativo categórico, podem ser estimulados, "pelo temor das penas ou pelo desejo das recompensas", a agir levando em conta as normas que garantem 0 exercício simultâneo da liberdade de todos. Assim, pode-se obrigar ao respeito, na medida em que se pode punir as formas reconhecidas de discriminação, aviltamento ou violência à autonomia alheia.

Para isto o Estado de direito tem duas ordens de regras: as que limitam o poder do soberano sobre a vida de seus súditos e as que limitam os poderes dos súditos entre si. Poucos terão descrito com mais precisão esta tirania de cidadãos sobre outros cidadãos quanto J.S. Mill no seu clássico estudo da liberdade civil. $\mathrm{Na}$ concepção democrática do Estado de direito, não se trata apenas da primeira questão, ou seja, de como a "sociedade civil" se defende contra o Estado, mas de como partes da sociedade civil se defendem de outras partes (e como as minorias se defendem das maiorias), e como as opiniões divergentes se garantem contra as opiniões dominantes. Neste sentido, espera-se do sistema jurídico que imponha tratamento isonômico, não discriminatório, e que regule as formas mais devoradoras de opressão, ou todas as formas de opressão, as formas dissimuladas da guerra de todos contra todos. É por isso que a impunidade, de que falei antes, é um elemento disfuncional no Estado de direito: ela atenta contra a isonomia. Além de dificultar a cooperação, a impunidade consolida discriminações e gera um código paralelo e informal, pervertendo o sistema formal de proibições e permissões: ela dá a impressão, ou melhor, ela estabelece, na prática, que o proibido é permitido para certos grupos.

Direitos de reconhecimento: fundamento para a cultura dos direitos humanos

Uma das arenas em que mais claramente se vê o fundamento dos direitos humanos na esfera da autonomia, em que a dignidade deixa de ser referência a um valor e passa a ser referida às pessoas, é a do chamado direito ao reconhecimento. Esta esfera, pela espécie de debate que suscita, mostra como pode ser limitada a defesa da autono- mia das pessoas humanas em função das tradições e tabus herdados acriticamente. ${ }^{7}$

Como já disse em outra oportunidade, houve no Brasil dos anos 80 um movimento forte em defesa dos direitos humanos que incorporava de modo explícito os direitos sociais à agenda permanente dos direitos humanos no Brasil. $\mathrm{Na}$ época, era notável a associação dos mais diferentes setores sociais, abrangendo um leque bastante heterogêneo de grupos, cada qual com suas perspectivas normativas mais ou menos indiferenciadas porque todos se uniam contra o regime militar então em processo de extinção.

A rigor, um dos elos que unia os diversos grupos era a defesa genérica dos direitos de redistribuição. Redistribuir riqueza e instalar no país uma ordem social-democrata, metas assumidas e implementadas há algum tempo nos países do capitalismo central, parecia 0 sonho realizável de democratização. Era uma perspectiva socializante ou socialista, para a qual, tradicionalmente, o que importa é reduzir as diferenças. Nestes termos, as questões de autonomia e diferença eram subordinadas ou ocultadas da agenda política. ${ }^{8}$ Em geral apresentou-se a democracia como 0 meio mais eficaz de promover simultaneamente 0 crescimento nacional, o desenvolvimento e a distribuição da riqueza. 0 longo percurso dos anos 80 e 90 veio desmentir parte dos sonhos. Pode-se dizer que até certo ponto o movimento pelos direitos humanos conseguiu ter sucesso neste ponto. Boa parte das pessoas se convenceu de que todos têm algum direito a um benefício social qualquer.

Quanto à questão das liberdades civis e à autonomia, o debate foi menor ou o movimento pelos direitos humanos teve resultados mais modestos. Algumas pesquisas recentes mostram como 0 brasileiro valoriza menos as liberdades democráticas (esfera da autonomia) do que os direitos sociais e patrimoniais (esfera da redistribuição). 0 Ibope, a pedido da Comissão Justiça e Paz de São Paulo, apurou dados importantes: na cidade de São Paulo, apenas 26\% dos entrevistados rejeitaram totalmente as violações graves dos direitos humanos. Dos $74 \%$ restantes, uma parte foi ambivalente (36\%), uma parte as apoiou parcialmente (21\%) e uma parte menor (17\%) as apoiou total- 
mente. A tortura foi apoiada por $66 \%$ dos entrevistados no Recife, $63 \%$ em São Paulo e $54 \%$ no Rio de Janeiro. Os direitos cuja violação parece mais grave para os entrevistados são justamente os de caráter social, ao passo que os direitos de liberdade política aparecem em último lugar. Creio que isto pode ser interpretado como a falta de reconhecimento do valor intrínseco do outro. 0 suspeito, o bandido, o que me ameaça merece um tratamento violento. 0 Estado (via polícia e via tribunais) deve ser meu vingador, deve fazer aquilo que eu pessoalmente não consigo fazer (cf. Cardia 1995a e 1995b).

Outra pesquisa significativa foi conduzida pelo Instituto Latinobarômetro em 1996 sobre a democracia e seu valor. Metade dos brasileiros (50\%) a defendeu, quase um quarto (24\%) disse preferir um regime autoritário e $21 \%$ disseram ser indiferentes. Vale dizer que para quase a metade dos brasileiros a democracia ou é má ou é indiferente, ou seja: as liberdades garantidas pelo Estado democrático não parecem importantes para a metade da população. Em números absolutos, o Brasil foi 0 país em que se verificou o menor índice de aprovação da democracia (no Uruguai o índice era de $80 \%$ e na Argentina de $71 \%$ ). Se comparada com a média latino-americana (que foi de $61 \%$ de apoio à democracia), a opinião pública brasileira poderia ser descrita como menos sensível à democracia.

Ao contrário das liberdades civis e dos direitos de reconhecimento, os direitos sociais têm um componente patrimonial que talvez os torne mais facilmente digeríveis para todos. Desde que se possa ter alguma coisa, é fácil acreditar que todos devam ter alguma coisa. Claro que se a situação for (como historicamente é) de escassez, os critérios de distribuição não são facilmente aceitos. Assim, os grupos "de baixo" parecem sempre fazer demandas espoliativas ou injustas com relação aos de cima. Esta a percepção obtida nas pesquisas realizadas (cf. Cardia, 1995a e 1995b). Curiosamente, a liberdade alheia parece desprezível, já que há uma cultura dominante do mérito, da punição e da moralidade que resulta na desvalorização da vítima cujo comportamento é "suspeito" e escapa às rígidas regras que determinam a vida alheia. ${ }^{9}$ Não é de espantar, portanto, que certas liberdades sejam pouco valorizadas, entre elas a de expressão e a de identidade ou orientação sexual. Tanto uma quanto a outra tendem a deslegitimar as formas tradicionais de vida aceitas e põem em dúvida, por sua própria existência, a validade de algumas tradições. "O erro não tem direitos" é o moto da tradição sobre as demandas inovadoras.

Entre redistribuição e reconhecimento

Os direitos sociais podem ser tratados como direitos de redistribuição de riqueza, seguindo a classificação de Marshall a respeito do desenvolvimento dos direitos fundamentais no 0 cidente. $^{10}$ Passou-se depois a falar de "novos direitos" ou de direitos de terceira e quarta gerações, que podiam variar da defesa do meio ambiente à defesa dos consumidores, dos interesses das futuras gerações e assim por diante. Uma análise esclarecedora é feita por Nancy Fraser (1997) - de quem tomo o título desta seção - , que distingue mais propriamente direitos de redistribuição de direitos de reconhecimento. O pano de fundo para a diferença é a política de identidades que se consolidou nos anos 80 e 90. Há casos paradigmáticos de política de identidade, que vão do movimento feminista aos movimentos dos negros e culminam com 0 movimento gay. A par destes, há também identidades que podem ser as reivindicações de grupos culturais, étnicos e lingüísticos minoritários, tais como se acham nos Bálcãs, na Ásia Central, no Canadá, nos grupos indígenas da América Latina. Política de identidade é um local próprio de reivindicações de direitos que chamamos de reconhecimento. Pode ter duas vertentes: a valorização positiva de certa identidade (e portanto a afirmação das diferenças), como se faz nos gay studies e no gay rights movement, ou a desconstrução das identidades (e do heterossexismo), como se faz na queer theory. A análise interessa porque valorizar os direitos ao reconhecimento é uma dificuldade a ser enfrentada pela cultura jurídica brasileira. Creio que justificar as diferenças é particularmente difícil no Brasil, onde nossa tradição é valorizar a assimilação, a miscigenação e 0 aculturamento, 0 espetáculo da "antropofagia", se quisermos.

Fraser lembra que as lutas por reconhecimento, ou identidade, dão-se num mundo de crescente 
desigualdade material (e, no caso brasileiro, da maior concentração de renda do mundo). Os direitos de redistribuição querem pôr fim à injustiça econômica, compensando ou transformando os mecanismos de mercado. Os direitos de reconhecimento querem dar remédio às injustiças culturais, pondo fim a certos universos simbólicos dominantes. Para a autora, os dois paradigmas modernos das "vítimas" das injustiças são, para os direitos de redistribuição, a classe operária (no capitalismo) e, para os direitos de reconhecimento, os homossexuais. Nas faixas intermediárias encontram-se os temas da raça e do gênero (negros e mulheres, no caso americano). Os homossexuais não são explorados como classe, pois estão em todas as classes:

[...] a injustiça que sofrem é essencialmente uma questão de reconhecimento. Gays e lésbicas sofrem de heterossexismo: a construção de normas de autoridade que privilegiam a heterossexualidade. Junto vem a homofobia: a desvalorização cultural da homossexualidade. Com sua sexualidade degradada, sofrem vergonha, assédio, discriminação, violência, enquanto seus direitos de proteção igual (isonomia) lhes são negados tudo fundamentalmente negativa de reconhecimento. Por certo, gays e lésbicas sofrem também sérias injustiças econômicas: podem ser despedidos sumariamente de empregos e lhes são negados benefícios sociais familiares. Mas longe de se enraizarem na estrutura econômica, estas injustiças derivam de uma estrutura injusta de valores culturais. (Fraser, 1997, p. 18)

Naturalmente, a própria redistribuição implica alguma forma de reconhecimento, o da igualdade de todos perante as necessidades materiais. Mas... como não só de pão vive 0 homem... a injustiça da desconsideração requer sua própria análise. Gostaria de acrescentar que 0 reconhecimento das diferenças, no caso paradigmático dos gays e lésbicas, enfrenta, na estrutura social brasileira, dificuldades peculiares justamente porque, como dito antes, é provável que nossa forma de solidariedade social ("de igreja") lide diferentemente com as diferenças. Quando, no Brasil, se faz a apologia da integração racial, creio que se está expressando justamente esta ideologia organicista, que "força todos a entrar" e, uma vez dentro, todos são iguais, mas alguns são subalternos.

Os direitos de reconhecimento têm um status específico, distinto dos direitos de redistribuição. A reivindicação do direito ao reconhecimento tem por finalidade garantir que certas identidades não sofram uma denegrição ou violência e que, simultaneamente, possam se expressar livremente sem temores. Em abril de 1997 um caso tomou conta do noticiário no Brasil: a gratuita, cruel e perversa violência que consistiu em queimar até a morte um índio que dormia na rua em Brasília. Violências semelhantes - gratuitamente semelhantes - costumam vitimar pessoas humanas que pertencem a grupos minoritários ou subalternos na sociedade (homossexuais, mas também crianças, mulheres, e assim por diante).

Qual o remédio adequado para a denegrição de certos grupos que termina estimulando a violência contra eles? Em primeiro lugar, de caráter penal: seja civil, seja criminalmente, o problema é tornar certas atitudes passíveis de penas (penas criminais ou civis, como indenizações), como se tem feito com o racismo. Outro remédio é garantir aos grupos minoritários liberdade de expressão: que possam manifestar-se publicamente sem que por isso sejam molestados pela polícia ou por outros grupos. Esta tem sido hoje a reivindicação dos grupos homossexuais, como foi outrora a de religiões minoritárias. Em terceiro lugar, demonstrar como o próprio sistema jurídico incorpora tratamentos que podem ser acusados de discriminatórios, como, por exemplo, a negativa aos parceiros de mesmo sexo de terem direito a licenças para tratamento de saúde do companheiro, ou a falta de garantias, no local de trabalho, de proteção à sua integridade moral.

$\mathrm{O}$ direito ao reconhecimento, diferentemente dos direitos à redistribuição, destaca 0 problema da liberdade da ação e da autonomia num sentido forte. Quero dizer que o reconhecimento integral da diferença do outro é forte na medida em que a tolerância que se exige é maior do que a simples indiferença das atitudes exclusivamente privadas. Pode-se dizer que uma coisa é tolerar que alguém tenha, no íntimo de sua casa, certo comportamento sexual. Outra coisa é admitir, publicamente, que 
qualquer um de qualquer orientação sexual possa expressar publicamente este aspecto integral de sua personalidade, de modo a não ser molestado, nem preterido no seu local de trabalho. Para fazer isto, o reconhecimento da dignidade humana dos outros é indispensável, e reconhecimento que não exija do outro que deixe de ser o que é, ou melhor, que oculte 0 que realmente é, desde que isto não cause dano a ninguém.

De fato, a "política de identidades" que hoje se desenvolve quer referir-se às identidades públicas. Não se trata apenas de defender a liberdade interior e, portanto, a liberdade do livre-arbítrio. A liberdade das identidades é uma espécie de liberdade civil, em que se possibilita a expressão pública daquilo que une ou identifica os grupos. Tomemos o exemplo da liberdade religiosa. Durante 0 Império era proibida a manifestação pública de cultos ou religiões que não fossem a religião oficial do Estado (a católica). Chegada a República, foram autorizadas as outras práticas. No entanto, os cultos associados à tradição africana, não ocidental, viam-se estigmatizados: eram praticados de forma clandestina muitas vezes e não raro entendidos como centros de contravenção ou delinqüência (curandeirismo ou charlatanismo, por exemplo). Não foi sem uma longa batalha jurídica e cultural que a liberdade religiosa se afirmou.

0 direito ao reconhecimento expressa-se em duas etapas. No primeiro momento, trata-se de garantir a simples sobrevivência do diferente e para isto valem os mecanismos jurídicos do direito penal, como criminalizar os atos de extermínio, isolamento e violência. Neste momento, o discurso justificador pode refletir-se nos direitos universais de vida e liberdade. Também neste momento busca-se uma definição adequada que separe esfera pública e esfera privada e limite a interferência do Estado aos casos em que a ação possa ser punida por delito cometido e que o delito seja definido de forma razoável e universal. Razoável quer significar, em primeiro lugar, que 0 delito causa um prejuízo a alguém. ${ }^{11}$ Num segundo momento, o direito exige que além de cessarem as perseguições e 0 extermínio, seja possível um reconhecimento positivo das diferenças, ou seja, que se minimizem os estigmas associados a certas identidades. Tem início uma atitude que leva à desconstrução das identidades anteriormente definidas, naquilo que têm de hierarquia e prescritividade. A luta pela identidade transforma-se na luta contra a exclusividade de modelos.

Se os direitos humanos têm algum fundamento no sentido de dignidade visto antes, seria possível incluir os direitos de reconhecimento dentro desta mesma tradição? Isto não se faria sem problemas quanto ao "pedigree" das idéias. Se a liberdade universal exige uma espécie de indiferença e a separação da esfera pública da esfera privada, como tratar do reconhecimento - agora como afirmação positiva das diferenças - sem romper com esta separação? Creio que a chave para a resposta está em admitir que as imagens que são feitas de certos grupos minoritários são depreciativas para cada sujeito que pertence a este grupo e constituem, neste sentido, uma violação pessoal e muitas vezes invisível de sua dignidade. Afirmar uma imagem positiva é tarefa que precisa desenvolver-se no espaço público, no mesmo que a denegrição se constrói e se mantém.

Esta, chamemos assim, dialética do público e do privado pode ser compreendida em termos hegelianos. Na Filosofia do direito, Hegel esboça 0 desenvolvimento do Espírito e da liberdade em duas linhas. Em primeiro lugar, diz que os institutos jurídicos considerados em si mesmos (pessoa, contrato, propriedade e responsabilidade - ou injustiça) são apenas o "direito abstrato", isto é, "não realizado". Ele é não realizado porque estes institutos têm como ponto de partida (e de chegada) apenas a vontade imediata, natural e empírica, incapaz de refletir e voltar a si, ou melhor, incapaz de universalizar-se. A propriedade é pensada como relação da vontade imediata e individual com as coisas, ou o contrato pensado como relação de duas vontades individuais e imediatas em conflito, e assim por diante. Nesta linha, o sujeito de direito é abstrato, individual e indeterminado. Isto é a primeira parte da sua Filosofia do direito: o direito civil, privado.

0 direito que se realiza como idéia precisa ser compreendido no universo das relações intersubjetivas, e a isto Hegel dedica a segunda parte da Filosofia do direito. Ali o que está em jogo é a moral 
e a ética (M oralität e Sittlichkeit). A primeira tenta compreender como a vontade infinita (imediata e natural) se transforma em vontade determinada, como a simples vontade (desejo) se transforma em vontade determinada (consciência). Este é 0 momento em que se poderia dizer que aparece parte das questões da moral transcendental (kantiana), que dizem respeito à consciência moral do sujeito individual. Está-se diante da moral subjetiva, da consciência, na qual não pode 0 direito interferir, visto que "não pode ser objeto da lei positiva".

O local próprio do direito é o da ética ou da moral objetiva. Aqui, o desenvolvimento da moral intersubjetiva propriamente dita toma forma (determina-se) em três esferas diferentes: a da família, a da sociedade civil e a do Estado. $\mathrm{Na}$ família os sujeitos se reconhecem pela afeição; na sociedade civil se reconhecem pelas necessidades (é 0 universo das trocas, independentemente dos afetos); no Estado os sujeitos se reconhecem como partes de um mesmo todo. Em cada uma destas esferas se compreendem os institutos jurídicos e em cada uma delas eles cumprem funções diferentes. Todos os níveis (ou esferas) se implicam. Um cidadão é solidário para com seus concidadãos, mas é também uma pessoa de afetos e de interesses econômicos. O sujeito é então, simultaneamente, divis, amicus, proximus, socius.

Com fundamento nesta perspectiva da constituição dos sujeitos por meio do reconhecimento em distintas esferas, Honneth (1996) fornece uma interpretação das "lutas por reconhecimento". As estratégias do reconhecimento nas relações afetivas da família permitem à pessoa ser reconhecida como criatura de necessidades. Nas relações jurídicas (na esfera da sociedade civil, em que o direito se realiza como lei e jurisdição, segundo Hegel), as pessoas são reconhecidas como sujeitos jurídicos abstratos.
Finalmente, dentro do Estado, são reconhecidas como universal concreto, sujeitos socializados em sua particularidade (cidadãos). 0 quadro que resume o processo de reconhecimento é o seguinte:

\begin{tabular}{|c|c|c|c|}
\hline \multicolumn{4}{|c|}{ Objeto de reoonhecimento } \\
\hline $\begin{array}{l}\text { M od } 0 \\
\text { de reconhe } \\
\text { cimento }\end{array}$ & $\begin{array}{c}\text { Indivíduo } \\
\text { (necessidades } \\
\text { concretas) }\end{array}$ & $\begin{array}{c}\text { Pessoa } \\
\text { (autonomia } \\
\text { formal) }\end{array}$ & $\begin{array}{c}\text { Sujeito } \\
\text { (particularidade } \\
\text { individual) }\end{array}$ \\
\hline $\begin{array}{l}\text { Intuição } \\
\text { (afetivo) }\end{array}$ & $\begin{array}{l}\text { família } \\
\text { (amor) }\end{array}$ & & \\
\hline $\begin{array}{l}\text { Conceitual } \\
\text { (cognitivo) }\end{array}$ & & $\begin{array}{l}\text { sociedade } \\
\text { civil (direito) }\end{array}$ & \\
\hline $\begin{array}{l}\text { Intuição int } \\
\text { (afeto feito }\end{array}$ & lectual & & $\begin{array}{c}\text { Estado } \\
\text { (solidariedade) }\end{array}$ \\
\hline
\end{tabular}

Relações de amor são laços emocionais fortes, dirigidas a um número determinado de pessoas. É o primeiro reconhecimento, em que cada um reforça e confirma o outro, ao mesmo tempo em que se cria dependência um do outro (Honneth, 1996, p. 95). Por isso, não é propriamente na família ou na esfera dos afetos que se dá a liberdade. Amar é ser si-mesmo no outro. $\mathrm{O}$ amor (incluindo todas as formas de amor, como a amizade) tem início em uma ligação emocional que não se controla ... é positivo mas não se estende à vontade refletida. No amor há sempre algo de particularismo, mesmo estando no centro de toda a vida ética. É este laço fundamental que produz a autoconfiança indispensável para a participação autônoma na vida ética. No direito - na sociedade civil aprendemos a dimensão do outro generalizado (idem, pp. 107-108).

A tabela seguinte mostra o desenvolvimento do sistema e também em que pontos se interrompe e se ativa a "denegrição" ou a incompreensão, ou a misrecognition (Honneth, 1996, p. 129).

\begin{tabular}{|c|c|c|c|}
\hline Modo de reconhecimento & A poio emocional & Respeito cognitivo & E stima \\
\hline $\begin{array}{lll}\text { Dimensão da } & \text { personalidade }\end{array}$ & Emoções e necessidades & Responsabilidade moral & Traços e habilidades \\
\hline Formas de reconhecimento & $\begin{array}{l}\text { Relações primárias } \\
\text { (amor, amizade) }\end{array}$ & $\begin{array}{l}\text { Relações jurídicas } \\
\text { (direitos) }\end{array}$ & $\begin{array}{l}\text { Comunidade de } \\
\text { valores (solidariedade) }\end{array}$ \\
\hline $\begin{array}{l}\text { Potencial de desenvolvimento } \\
\text { Relacão prática com } 0 \text { eu (selff }\end{array}$ & $\begin{array}{c}- \\
\text { Autoconfianca básic }\end{array}$ & $\begin{array}{l}\text { Generalização, desformalização } \\
\text { Auto-respeito }\end{array}$ & $\begin{array}{l}\text { Individualização, eqüalização } \\
\text { Auto-estima }\end{array}$ \\
\hline Formas de desrespeito & $\begin{array}{l}\text { Abuso e violência } \\
\text { (estupro, v.g.) }\end{array}$ & Negação de direitos & Insulto, injúria, denegrição \\
\hline $\begin{array}{ll}\text { Componente da } & \\
\text { personalidade } & \text { ameaçado }\end{array}$ & Integridade física & Integridade social & dignidade \\
\hline
\end{tabular}


A denegricão, 0 não reconhecimento ou 0 desrespeito à dignidade alheia têm várias formas. A primeira é (a) o abuso físico, que nega a possibilidade de o outro estar seguro no mundo. A segunda forma consiste em (b) excluir alguém de uma esfera de direitos. A negativa de direitos tanto pode dar-se por meio da segregação (explícita) quanto por "ostracismo social": não só se impede a autonomia social, mas impede-se um parceiro para a interação.

A espécie de reconhecimento de que se priva nesta espécie de desrespeito é o respeito cognitivo ao status da responsabilidade moral que foi tão duramente adquirido no processo de socialização interativa. Esta forma de desrespeito representa uma quantidade historicamente variável porque 0 conteúdo semântico do que conta como agente moralmente responsável muda com o desenvolvimento das relações jurídicas. Portanto, a experiência da negação de direitos é sempre medida não só em termos do grau de universalização, mas também em termos do objetivo substancial dos direitos institucionalmente estabelecidos. (Honneth, 1996, p. 133)

Uma terceira forma de desrespeito consiste (c) na negativa de valor a uma forma de vida ou de ser. Tanto de um grupo étnico, quanto de um grupo lingüístico, cultural, ou de orientação sexual que constrói progressivamente alguma identidade coletiva. Este desrespeito consiste no tratamento insultuoso ou degradante e leva em conta modos de vida individuais ou coletivos.

Para as pessoas, este tipo de desvalorização social traz consigo tipicamente uma perda da autoestima, da oportunidade de se verem como sujeitos cujos traços e habilidades são considerados. Assim, a espécie de reconhecimento que este tipo de desrespeito nega à pessoa é a aprovação social de uma forma de auto-realização que ele ou ela teve que descobrir a despeito de todos os obstáculos, com o encorajamento da solidariedade do grupo. Claro, a pessoa só pode ligar estas formas de degradação cultural a si como indivíduo, já que os padrões de estima firmados institucionalmente foram historicamente individualizados, isto é, uma vez que os padrões se referem avaliativamente a traços individuais em vez de a traços coletivos. Logo, esta experiência de desrespeito, assim como a negativa de direitos, está ligada a um processo de mudança histórica. (Honneth, 1996, p. 134)

Taylor (1994, p. 26) conclui que a falsa idéia, o preconceito, "a misrecognition demonstra não apenas falta de respeito devido. Eles podem provocar ferida grave, impondo a suas vítimas um ódio a si mesmas (self hared, que é mais do que falta de amor-próprio) que as aleija 0 devido reconhecimento não é uma simples cortesia que devemos às pessoas: é uma necessidade humana vital". Na É tica da autenticidade, o autor completa 0 círculo do reconhecimento em termos hegelianos, colocado na esfera pública e não na esfera das relações intersubjetivas primárias, face a face: 0 reconhecimento que se espera é público, não simplesmente privado, pois o que oprime não é a falta de reconhecimento afetivo, que se pode encontrar em círculos restritos, mas a falta de reconhecimento preconceituoso que atinge indiscriminadamente a qualquer um do grupo. A falta de reconhecimento público, por seu turno, transfere-se para a vida privada. Esta imagem pública oprime gravemente, diz ele, porque é introjetada (Taylor, 1991). Por causa deste aspecto público e universal, o princípio de reconhecimento da diferença nos modos essenciais de identidade pode ser afirmado como princípio de justiça.

0 reconhecimento exige que se abra o espaço público para a reconstrução de identidades de grupos minoritários tradicionalmente discriminados, desvalorizados ou olhados com preconceito. Daí que uma das esferas em que se dá a luta pelo reconhecimento seja a do desenvolvimento de um orgulho coletivo: orgulho dos negros, dos gays e lésbicas, dos judeus, dos povos indígenas etc. Garantem-se juridicamente duas coisas: a integridade individual e a integridade de grupos tradicionais ou em construção.

0 auto-respeito é a base de todos os bens primários, pois é ele que permite ao agente definirse como sujeito propriamente dito. Assim, não só liberdade, oportunidades, riqueza e renda com- 
põem os bens primários. E uma sociedade justa deve garantir primariamente "as bases sociais do auto-respeito" (Rawls, 1992, pp. 440 e 62).

0 reconhecimento distingue-se, portanto, da construção da igualdade material e tem, creio eu, uma precedência lógica sobre ela. 0 sentido de dignidade - que as idéias de autonomia, estima pública, auto-estima e reconhecimento traduzem —, e dignidade do agente e do sujeito, é prévio à idéia de distribuição de riqueza. Em outras palavras, a distribuição de riqueza - a igualdade material — só é moralmente devida se houver inicialmente uma consideração pela pessoa, ou uma metafísica da pessoa. A metafísica da pessoa livre é, portanto, a razão de ser da busca de equalização de condições de vida. 0 respeito é devido ao outro que se reconhece como sujeito de direitos ou sujeito moral. E este respeito é devido também à identidade coletiva, pelas razões expostas por Taylor: a falsa imagem do outro, por sua diferença, é uma deficiência que os grupos dominantes criam e impõem aos grupos subalternos.

Só o princípio da liberdade - como autonomia e liberdade civil - permite isto, 0 reconhecimento de forma universal. Ele também justifica, em última análise, as regras distributivas, pois, afinal, distribuir é dar a parte de cada um que se considera parte efetiva do todo. De outra maneira, a distribuição desigual tornar-se-ia perfeitamente aceitável, já que as desigualdades ditas "naturais" e as desigualdades hierárquicas (da honra, da maior dignidade etc.) conviveriam bem com a desigualdade de liberdade e de riqueza (ou satisfação de necessidades).

A exigência de respeito não tem por alvo tanto a equalização das condições de vida quanto a proteção da integridade de formas de vida e tradições nas quais os membros de grupos discriminados podem se reconhecer. Normalmente, claro, a falta de reconhecimento cultural está ligada a discriminações sociais e as duas se reforçam reciprocamente. (Habermas, 1994, p. 110)

A falta de reconhecimento nem sempre tem uma conseqüência econômica direta. Por isso os direitos ao reconhecimento são autônomos em relação aos direitos de distribuição, ou direitos sociais, e é equivocado pensar que o reconhecimento virá como conseqüência pura e simples da distribuição, ou mesmo que a distribuição tem precedência sobre o reconhecimento. Isto levou Boswell (1981) a escolher a marginalização dos homossexuais na história ocidental como o caso paradigmático de exclusão (ou opressão) e intolerância, a despeito das muitas perseguições que outros grupos sofreram. Ele não quer dizer que os gays foram o grupo que mais sofreu perseguições numericamente falando, nem que, quantitativamente, foram a população mais cruelmente tratada.

O caráter exemplar de sua marginalização está em outra parte. Para Boswell, os homossexuais, ao contrário de judeus e muçulmanos no mundo medieval, estavam dispersos em toda a população e constituíam, então, como sempre, uma minoria significativa da população (os hereges apareciam aos surtos periódicos). Ao contrário dos pobres, nunca foram maioria. A intolerância contra eles não se confundia (até o século XIX) com aquela dedicada a doentes, menores e mulheres, que precisavam ser vigiados por sua incapacidade ou pelo risco da contaminação. Ao contrário de judeus ou católicos, gays não nascem dentro de famílias gays e sofrem individual e isoladamente a opressão, sem o conforto de um conselho, do apoio emocional dos mais próximos, dos mais velhos. São socializados como membros comuns da sociedade, pois os pais não percebem que seus filhos são gays senão muito tarde. Em todos os aspectos da vida, menos em um, são completamente iguais a todos. Por isso, conclui Boswell, a má vontade com relação a eles é tão esclarecedora da intolerância em si mesma. Quando a sociedade é intolerante, eles são invisíveis, dada a natureza íntima de sua diferença, o que amplia seu isolamento e ao mesmo tempo impede que se desenvolva a cultura da resistência. Não há pais ou avós para relembrarem a perseguição, não há festas, memória ou celebração de seus mortos, mártires ou heróis. Também por isso são um grupo fragilizado coletivamente (não só individualmente, pois cada um desenvolve sua estratégia de sobrevivência) e dependente de atitudes populares e não críticas com relação a eles. "A história da reação 
contra os homossexuais" - diz 0 autor - "é de certo modo a história da intolerância em geral." (Boswell, 1981, pp. 5 e 16).

E o direito brasileiro, o que pode ter a ver com isso? Para alguns, desde que o Código Criminal do Império, de 1830, não incluiu as relações homossexuais entre adultos como crime, a questão estaria resolvida. Já então teríamos entrado no mundo do respeito às diferenças. É certo que uma parte da questão foi ali encaminhada. Mas isto seria 0 mesmo que dizer que depois da reforma eleitoral dos anos 30, que deu às mulheres o direito de voto, e do Estatuto da Mulher Casada de 1962, que lhe deu plena igualdade com o marido, as mulheres já não teriam com o que se preocupar do ponto de vista jurídico e o seu movimento deveria esvaziar-se.

Os problemas a exigir soluções jurídicas não são poucos. Basta ler o relato de Luiz Mott (1996) sobre 0 assunto. Pesquisas mostram que os homossexuais são o grupo mais rejeitado e odiado pelos brasileiros (78\% entre a população em geral; $82 \%$ entre os formadores de opinião). 0 estigma e a homofobia (temor e ódio irracionalmente inspirados) provocam violências no âmbito familiar, nas escolas e no emprego. Não é exato dizer que os homossexuais são vítimas da mesma violência que qualquer um: os crimes cometidos contra eles, especialmente os homicídios, são acompanhados de crueldades inenarráveis muitas vezes, alimentadas pela homofobia estimulada por setores conservadores da sociedade, e sua vitimização é específica. Assim como o crime de genocídio difere do simples homicídio, ainda que este se faça com requintes de crueldade, o crime de ódio (hate crime) é também específico: há um dolo específico, uma vítima (ou grupo de vítimas) diferente, há um propósito distinto. Gays e lésbicas são também discriminados no trabalho, seja para não serem admitidos (há lugares em que se aplicam testes para detectar a orientação sexual dos candidatos), seja para impedi-los de serem promovidos (os solteiros são tratados como menos confiáveis, e assim por diante). São, pois, pela sua orientação sexual, barrados em carreiras e empregos públicos e privados (Mott, 1996). Em São Paulo, relata Mott, 40\% das recusas de candidatos a empregos são atribuídas à orientação sexual homoerótica (candidatos ditos efeminados), e Lima (1983) relata os muitos casos de impedimento de acesso a empregos. São barrados em bares e outros locais públicos em nome dos bons costumes. E até hoje, lembra o mesmo Mott, os grupos de direitos humanos mantêm uma "discreta omissão" (digo eu) sobre o tema. ${ }^{12}$

Por vários motivos, portanto, a discriminação contra os homossexuais é paradigmática de todas as formas de opressão cultural. Até mesmo 0 argumento de que se trata de uma questão exclusivamente privada é significativo. Ele importa dizer que o sofrimento causado pelo abuso (físico e moral) e pela discriminação deve ser suportado individualmente, contra uma prática social e pública de violências (físicas e morais) que continua sendo estimulada e tende a ficar impune. 0 argumento de que se trata de uma questão menor dentre tantas questões mais importantes e urgentes é ainda mais exemplar: significa dizer que 0 respeito devido à pessoa pode ser colocado em segundo lugar diante de outras necessidades, ou que a necessidade de reconhecimento e tratamento digno pode ser colocada em segundo plano perante as necessidades materiais de um, de muitos ou de todos.

\section{Conclusão}

Se argumentos contra a autonomia persistem e recebem algum apoio é porque são significativos de um ethos, de uma atitude de desrespeito à liberdade e à dignidade. Existe, parece-me, um problema de fundo na sociedade brasileira que a torna conflitante com uma concepção universal e democrática dos direitos humanos. Creio que isto, inclusive entre juristas, tem influência sobre as vicissitudes dos direitos da pessoa humana entre nós. Trata-se do valor (ou da falta de valor) atribuído à noção de autonomia. A autonomia e a inviolabilidade da pessoa são dois eixos para a definição desses direitos. A autonomia implica diferença e dissonância. Pode-se dizer que a assimilação e a diferenciação compõem dois pólos entre os quais o direito se equilibra. Regras que estimulam a cooperação e regras que estimulam a competição parecem antagônicas e formam, a bem dizer, 0 arcabouço jurídico das sociedades pós- 
tradicionais. A diferenciação pede que 0 sistema jurídico sancione as tentativas de pôr fim a indivíduos ou a grupos pelo fato de serem diferentes. A cooperação pode sugerir que certas igualdades sejam criadas. A igualdade perante a lei, por exemplo, é uma delas.

É preocupante que a diferenciação seja pouco valorizada entre nós. D esprezada, transforma-se facilmente em desvalorização das liberdades civis e ambiente hostil para a defesa dos direitos humanos. E não se pode sem mais atribuir este aspecto da intolerância social ao poder do Estado, embora se possa dizer que a forma pela qual o Estado brasileiro foi desenvolvido tenha algo a ver com isto. No que diz respeito aos direitos de reconhecimento, contra a discriminação, há um longo caminho a ser percorrido. Basta dizer que tais direitos contrapõem-se a práticas tradicionais, cujo ritmo de mudança é lento e constantemente dificultado pela aceitação majoritária e acrítica de certos preconceitos. Como lidar juridicamente com o preconceito? Vários mecanismos são necessários, e em geral eles tendem a criar especial proteção para grupos especialmente vulneráveis. A igualdade jurídica nestes casos constrói-se por meio da desigualdade, isto é, por conceder diferentes formas de proteção aos grupos discriminados. É contra isto que se voltam aqueles que falam de direitos especiais: seria antidemocrático conceder "direitos especiais" a certos grupos. Nada mais equivocado, porém: 0 direito do trabalho, 0 direito das crianças e muitos outros microordenamentos, como se diz na teoria jurídica, são exemplares da proteção especial dada (e devida) a grupos vulneráveis. Já que se trata de minorias, é preciso que o sistema jurídico conceda a tais grupos os instrumentos legais suficientes para que possam sobreviver em meio aos outros grupos.

Estes instrumentos são semelhantes aos desenvolvidos para conter ou barrar os preconceitos. Há uma certa dificuldade, pois é preciso bem compreender o âmbito ou a extensão daquilo que é o espaço público. O preconceito de cor, por exemplo, vai aos poucos sendo combatido em âmbitos que décadas atrás seriam considerados espaços exclusivamente domésticos ou privados: os clubes, os elevadores de edifícios de apartamen- to, os empregos na iniciativa privada. 0 mesmo precisará ser feito com relação aos outros grupos marginalizados, cujo tratamento subalterno, opressivo e desigual vai pouco a pouco sendo percebido. Levará um bom tempo para que a cultura se altere e que o estigma da imagem de muitos destes grupos seja minimizada. Muitos, como os homossexuais, nem mesmo são uma comunidade propriamente dita: trata-se de um grupo de identidade resultante de características comuns, cujos membros se encontram em todas as classes, etnias, regiões geográficas. Trata-se uma parcela da população de aptidões, qualidades, origens, condições sociais, orientação política e crenças de variedade infinita (cf. Mécary e La Pradelle, 1998). ${ }^{13}$ A única coisa que essas pessoas têm em comum é a hostilidade, a violência de que são vítimas isolada e individualmente, como resultado de uma visão distorcida e irracional que se construiu em certas sociedades ao longo da história. Os direitos democráticos vêm permitindo que surjam como grupos de interesse na vida política contemporânea e que, a despeito da enorme variedade de suas vidas particulares, possam apresentar exigências jurídicas contra 0 tratamento que recebem por sua "pertença" ao grupo social e juridicamente discriminado.

A hostilidade à cultura dos direitos humanos, pela impunidade seletiva ou pela falta de sensibilidade às diferenças, não é só um fenômeno brasileiro. Os números, no entanto, são demasiado evidentes aqui para indicar problemas específicos que vêm tanto do sistema jurídico (compreendendo como sempre as normas, a cultura jurídica dominante e as instituições) quanto da "sociedade em geral".

\section{NOTAS}

1 Assumo que o compromisso moderno é importante e bom, conforme sumariado por Pufendorf: posso conviver com quem tenha idéias diferentes das minhas, desde que não me cause nenhum mal. Uma concepção de direitos humanos de caráter religioso requereria a aceitação de princípios religiosos, o que nas sociedades pósindustriais não é nem viável nem, a meu ver, desejável.

2 Folha de S. Paulo, 12/ 2/ 1997, caderno 1, p. 7. 
3 A expressão justiça seletiva é usada por José Eduardo Faria; justiça lotérica, por Wanderley Guilherme dos Santos (1993).

4 O resultado da não cooperação é a chamada "tragédia dos bens coletivos" ou "tragédia das coisas comuns" (the tragedy of the commons), objeto de um clássico ensaio de Garret Hardin (1968). O problema vem sendo retomado em estudos de ecologia, especialmente McCay e Acheson (1996) e Hardin e Baden.

5 A riston é a forma superlativa de agathon, o bom. Assim, os melhores eram também os mais dignos nas sociedades em que a dignidade é uma honra distribuída a alguns apenas, não a todos.

6 Neste nível das escolhas e do desenvolvimento da capacidade de descobrir e fundar regras estamos no centro de um debate propriamente filosófico, que abrange o conceito de regra e a forma pela qual se adquire 0 ponto de vista normativo e crítico. Há um enorme debate que não vem ao caso aqui, embora possam ser referidas as vertentes da ética do discurso e da filosofia analítica como duas contribuições importantes.

7 Uma primeira abordagem geral do tema encontra-se em Lopes (1995)

8 Para ver isto do ponto de vista teórico consulte Nancy Fraser (1997). Do ponto de vista empírico, no caso das esquerdas brasileiras, ver Lima (1983, pp. 159-164).

9 Cf. nota 8.

10 Embora fale-se sempre da tese de Marshall, apresentada em 1949, é bom lembrar que Carl Schmitt já havia feito semelhante análise em 1927 no seu Teoria da ConstituiÇã 0 .

110 prejuízo a ser evitado não é qualquer um. Por exemplo, se rompo um relacionamento amoroso, 0 prejuízo do rompimento propriamente dito não seria considerado, nas atuais circunstâncias, daquela espécie que gera responsabilidade penal, embora possa gerar algumas formas de responsabilidade civil. Isto quer dizer que posso, sem estigmas, romper o relacionamento sem cometer crime. De outro lado, conforme a célebre disputa entre H.L. Hart e Lord Patrick Devlin, sobre a descriminalização do homossexualismo no Reino Unido, é preciso distinguir entre 0 prejuízo à "decência" tradicional, que pode ser apenas o sentimento de repulsa (disgust), e que pode contar como um circunstancial problema de conveniência política, e 0 prejuízo à pessoa humana. Dworkin lembra que uma moral crítica exclui de sua consideração certos argumentos: 0 preconceito (opinião recebida), as aversões afetivas pessoais, as bases empíricas falsas, a opinião alheia (argumento de autoridade). Para esta discussão em particular ver Dworkin (1978), Hart (1963) e Devlin (1991).

12 Em junho de 1996 dois bares gays de São Paulo sofreram a invasão de skinheads, resultando na morte de um freqüentador, sem que, como bem disse Luiz Mott, as entidades de direitos humanos tivessem protes- tado imediata e adequadamente contra 0 ato neonazista (Mott, 1996, p. 139).

13 Haveria muito a dizer sobre a construção da identidade e da comunidade. Basta apenas mencionar que uma comunidade de interesses é compatível com a noção moderna de cidadania. Podemos não ter muito em comum com os outros membros de nossa sociedade atomizada e pluralista, mas temos pelo menos o desejo de segurança e de respeito universal. São as condições básicas de uma democracia, como queriam os clássicos da modernidade, entre eles Rousseau e Kant. A consciência da opressão comum, que se adquire com 0 desenvolvimento da visibilidade, por exemplo, constitui uma espécie de "comunidade política". Assim, a própria exclusão e discriminação promovem dialeticamente a existência da "comunidade" de interesses, que depois se desenvolve de formas variadas. Esta comunidade de interesses é uma "comunidade de direitos" e encontrase na base de algumas teorias fundamentais de direitos humanos, como a de Alan Gewirth (1996).

\section{BIBLIOGRAFIA}

APPIAH, Kwame A. (1998), "Patriotas cosmopolitas". Revista Brasileira de Ciências Sociais, Anpocs, 13, 36: 79-94.

BOSWELL, John. (1981), Christianity, social toleranoe and homosex uality. Chicago, University of Chicago Press.

CALDEIRA, Teresa Pires do Rio. (1991), "Direitos humanos ou privilégios de bandidos?". N ovos E studos, São Paulo, Cebrap, 30:162-174.

(1992), City of walls: crime, segregation, and citizenship in São Paulo. Ph.D. dissertation, Berkeley University.

CARDIA, Nancy. (1995a), D ireitos humanos: ausência de cidadania e exclusão moral. São Paulo, Comissão Justiça e Paz de São Paulo.

. (1995b), "Direitos humanos e exclusão moral". D ireitos H umanos no Brasil, São Paulo, Núcleo de Estudos da Violência/ Comissão Teotônio Vilela, n. 2.

DEVLIN, P. (1991), "Morals and the criminal law", in R. Dworkin (ed.), The philosophy of law, Oxford, Oxford University Press.

DWORKIN, Ronald. (1978), "Liberty and moralism", in R. Dworkin, Taking rights seriously, Cambridge, Mass., Harvard University Press.

(ed.). (1991), The philosophy of law. Oxford, Oxford University Press. 
ELSTER, Jon. (1994), The cement of society. Cambridge, Cambridge University Press.

FRASER, Nancy. (1997), Justice interrupts. Nova York/ Londres, Routledge.

GEWIRTH, Alan. (1996), The community of rights. Chicago, University of Chicago Press.

GUTMAN, Amy. (1994), "Introduction", in Amy Gutman (ed.), Multiculturalism, Princeton, Princeton University Press.

HABERMAS, Jürgen. (1994), "Struggles for recognition in the democratic constitutional state", in Amy Gutman (ed.), Multiculturalism, Princeton, Princeton University Press.

HARDIN, Garret. (1968), "The tragedy of the commons. The population problem has no technical solution: it requires a fundamental extension in morality". Science, 162, D ecember: 1.243:1.248.

HARDIN, Garret e BADEN, J. (eds.). The commons. San Francisco, W.H. Freeman \& Co.

HARG REAVES, Shaun P. Heap e VARO UFAKIS, Yanis. (1995), Game theory: a critical introduction. Londres, Routledge.

HART, H.L. (1963), Law, liberty and morality. Stanford, Stanford University Press.

HOLANDA, Sérgio Buarque de. (1963), Raízes do Brasil. $4^{a}$ ed., Brasília, Ed. da UnB.

HONNETH, Axel. (1996), The struggle for recognition: the moral grammar of social conflicts. Cambridge, Mass., The MIT Press.

LEAL, Aurelino. (1922), "História judiciária do Brasil", in Instituto Histórico e Geográfico do Brasil, Diocionario historioo, geographico e ethnographico do Brasil, Rio de Janeiro, Imprensa Nacional.

LIMA, Delcio Monteiro de. (1983), Os homoerótioos. Rio de Janeiro, Francisco Alves.

LOPES, José Reinaldo de Lima. (1995), "Justiça, identidade e liberdade", in Elisa Reis et al., Pluralismo, espaşo social e pesquisa, São Paulo, Hucitec.

LUCAS, J.R. (1989), On justiœ. Oxford, Clarendon Press.

McCAY, B. e ACHESO N, J. (eds.). (1996), The question of the commons: the culture and ecology of communal resources. Tucson, University of Arizona Press.
MÉCARY, Caroline e LA PRADELLE, Géraud. (1998), $L$ es droits des homosexuelles. $2^{a}$ ed., Paris, PUF.

MILL, John Stuart. (1974), Utilitarianism e On liberty. Organizado por Mary Warnock, Nova York, Meridian.

MOTT, Luiz. (1996), “Os homossexuais: as vítimas principais da violência", in Gilberto Velho e Marcos Alvito (orgs.), Cidadania e violência, Rio de Janeiro, Ed. da UFRJ/ Fundação Getúlio Vargas.

NINO, Carlos S. (1992), Un país al margen de la ley. $2^{\text {a }}$ ed., Buenos Aires, Emecé Editores.

OLIVEIRA, Luciano. (1996), “Tolerância, liberdade, democracia: algumas questões", in Márcio Fabri dos Anjos e José Reinaldo de Lima Lopes (orgs.), É tica e direito: um diálogo, Aparecida, Santuário.

OLSON, Mancur. (1971), The logic of collective action. Cambridge, Mass., Harvard University Press.

RAWLS, John. (1992), A theory of justioe. Oxford, Oxford University Press.

REIS, Elisa. (1995), "D esigualdade e solidariedade: uma releitura do familismo amoral de Banfield". Revista Brasileira de Ciências Sociais, Anpocs, 10, 29: 35-48.

RICOEUR, Paul. (1995), "Tolerância, intolerância, intolerável", in Paul Ricoeur, Em torno do polítion, tradução de Marcelo Perine, São Paulo, Loyola.

SANTOS, Wanderley G. dos. (1993), Razões da desordem. Rio de Janeiro, Rocco.

SOUZA, Jessé. (1998), "A ética protestante e a ideologia do atraso brasileiro". Revista Brasileira de Ciências Sociais, Anpocs, 13, 38: 98-116.

TAYLOR, Charles. (1991), The ethics of authenticity. Cambridge, Mass., Harvard University Press.

(1994), "The politics of recognition", in Amy Gutman (ed.), Multiculturalism, Princeton, Princeton University Press.

(1996), Souroes of the self. Cambridge, Cambridge University Press.

VIANNA, Oliveira. (1987), Instituicões políticas brasileiras. Vol. 2. Belo Horizonte/ São Paulo/ Niterói, Itatiaia/ Edusp/ Ed. da UFF. 